Original Research Paper

\title{
Investigation and Comparison of the Quantitative and Qualitative Frequency Distribution of the Rivers
}

\author{
${ }^{1}$ Saeid Eslamian, ${ }^{2}$ Mahboubeh Amoushahi-Khouzani, ${ }^{3}$ Iman Malekpour, \\ ${ }^{4}$ Arezou Babaahmadi, ${ }^{5}$ Kaveh Ostad-Ali-Askari, ${ }^{6}$ Vijay P. Singh and ${ }^{7}$ Mohsen Ghane \\ ${ }^{I}$ Department of Water Engineering, Isfahan University of Technology, Isfahan, Iran \\ ${ }^{2}$ Department of Water Engineering, Science and Research Branch, Islamic Azad University, Tehran, Iran \\ ${ }^{3}$ Department of Civil and Environmental Engineering, University of Iowa, Iowa City, Iowa, USA \\ ${ }^{4}$ Chalmers University of Technology, SE-41296 Gothenburg, Sweden \\ ${ }^{5}$ Department of Civil Engineering, Isfahan (Khorasgan) Branch, Islamic Azad University, Isfahan, Iran \\ ${ }^{6}$ Department of Biological and Agricultural Engineering and Zachry Department of Civil Engineering, Texas A and $M$ \\ University, 321 Scoates Hall, 2117 TAMU, College Station, Texas 77843-2117, USA \\ ${ }^{7}$ Department of Hydraulic Structures, South Tehran Branch, Islamic Azad University, Tehran, Iran
}

Article history

Received: 23-08-2017

Revised: 23-09-2017

Accepted: 04-10-2017

Corresponding Author:

Dr. Kaveh Ostad-Ali-Askari

Department of Civil

Engineering, Isfahan

(Khorasgan) Branch, Islamic

Azad University, Isfahan, Iran

Email: koa.askari@khuisf.ac.ir

kaveh.oaa2000@gmail.com

\begin{abstract}
The entrance of pollutants from human activities to the surface water has seriously threatened the quality of water. TDS is an important qualitative parameter of water that describes the water salinity by measuring the concentration of total dissolved solids. First, using TDS and discharge data of the Cuyahoga River, Ohio, the partial and annual data sets were obtained. Then, partial data with three thresholds of $n$, $1.64 \mathrm{n}$ and $2 \mathrm{n}$, in which $\mathrm{n}$ is the number of statistical years were developed and using the Hyfa Software, the frequency distribution of the data series was done. The results showed that for most cases, the two-parameter Log-normal distribution is the best distribution. Finally, for model validation, the error corresponding to each estimation was first calculated in comparison to the real data for the corresponding return periods. Then, $1.64 \mathrm{n}$ partial series was considered as the optimum method suggested by Hasking and a comparison was made between the estimates and this optimum series. The results showed that the series with a length of $2 \mathrm{n}$ was closest to the optimum case.
\end{abstract}

Keywords: Water Quality, TDS, River Discharge, Frequency Distribution, Two-Parameter Log-Normal, Water Resources Management

\section{Introduction}

Humanity has entered the modernity for decades, an era combined with massive building, an era in which human beings felt the nature in their hands. However, by looking back, we face environmental catastrophes. Some organisms have become extinct, the water is polluted and the nature has become more manageable and vulnerable day after day. Now, after years of experience, humans want to progress alongside nature to have a clean, green world forever. Freshwater sources are essential elements of the environment and life and human life on the planet depends on the qualitative and quantitative water supply. In the past, there was a weak management and development of water resources and because of the abundance of water resources, their pollution issues, including those caused by the entrance of wastewater, were not of utmost importance. Water quality management is linked to pollution control caused by human activities. In fact, water quality management is an awareness of the quantitative and qualitative status of a water resource (Alizadeh, 2005). In general, the purpose of water quality management is to protect water resources so that the water intended can be used for uses that were already intended for it and it can be used as an economic agent for the disposal of waste in emergency situations and it should also have the capacity to mix and tolerate these materials. 
In this study, TDS and discharge data of the Cuyahoga River, Ohio, USA were collected. TDS is the water salinity index and indicates the concentration of cations and anions in water as the concentration of total dissolved solids. TDS is one of the most important indices of water quality in terms of water use capability for various uses. For example, the concentration of the soluble salts in drinking water should not exceed $500 \mathrm{mg}$ $\mathrm{L}^{-1}$, but higher concentrations can be considered for livestock. This is more critical in plants and therefore, quality of irrigation water is very important for agricultural use. By increasing the concentration of salts in irrigation water to more than $500 \mathrm{mg} \mathrm{L}^{-1}$, water and soil management becomes especially important in maintaining product efficiency (Al-Boodi et al., 2002; Raeisi-Vanani et al., 2017).

As noted, surface water has different salinities and most of the industrial wastewater entered to the surface water has significant amounts of salt that would add to the concentration of salts in these water resources. Rainfall runoff would also wash the salts on the surface of roads and fields and thus, a large amount of salt is discharged into surface and groundwater. In addition to the above mentioned issues, the supply of fresh water by sweetener devices will increase the salinity of the remaining water. Therefore, the volume of sweet water on the earth surface is reduced and salty waters are increased day by day (Efran Manesh and Afyoun, 2005).

In this study, HYFA statistical software was used, which is a hydrological software to estimate the maximum probable discharge for different return periods. The software can import data in the form of files or during the runtime and correct and save it. Using this program, the data is sorted and using the seven available experimental formulas, its probability of occurrence is determined (Eslamian et al., 2005; Ostad-Ali-Askari et al., 2017a). Then, the data is fitted by using the six probability density distribution functions and the distribution parameters are estimated. The software can do the followings:

- Evaluation of the statistical distribution fitting to the hydrologic data, by using both the moments and maximum accuracy methods

- Estimation of the probable discharges, calculation of the standard error and the confidence limits according to a set of selected return periods

- Performing the fit goodness test according to the Chi-square method and the Deviation method, that is one of the subsets of the Least Square method

In the present study, 12 years of qualitative and quantitative river statistics were available, which is very short. In general, the more detailed and complete the statistics are, the higher the quality of the investigation, the more accurate and reliable the results. Qualitative TDS data and quantitative discharge data of the Cuyahoga River were collected. The aim of the study was to do a qualitative and quantitative prediction and to investigate whether a comparative quantitative and qualitative analysis can be done using the frequency analysis methods and which statistical distribution should be fitted to the data for prediction and which statistical distribution can be used in practice (Eslamian and Koopani, 2002; Fakhri et al., 2014).

\section{Materials and Methods}

The study area, Cuyahoga River was located in North Ohio, USA. Native Americans named the river Cuyahoga, which means a curved or bent river due to its shape. The river is one of the young geological structures that has been formed by the advancement and withdrawal of ice layers during the ice years. The last ice withdrawal, which happened about 10,000 years ago, led to a redirection and formation of a U-shaped river. The depth of the river is between 3 and 6 feet (Gupta, 1989; Thomann, 1982; Ostad-Ali-Askari et al., 2015; Shayannejad et al., 2015a; 2015b; 2017).

The first 100 miles of the river is located around the Ceauga County. Then, the river continues toward the South to Cuyahoga Falls, as far as it turns toward the North with a steep curve and continues inside the Cuyahoga National Park and in the Cleveland toward its northern outlet and eventually discharges to the Erie Lake.

In this study, 80 TDS and discharge data from the Cuyahoga River for 12 years were available, a can listed in Table 1. The lengths of partial series data were obtained as $\mathrm{n}, 1.64 \mathrm{n}$ and $2 \mathrm{n}$ using the existing equations, where $n$ is the number of statistical years. Table 2 to 5 show different cases. (Dehghan et al., 2017; Bahmanpour et al., 2017; Shojaei et al., 2017; Saadati et al., 2006; Raeisi-Vanani et al., 2017a; 2017b; 2015).

Table 1. Cuyahoga river characteristics

\begin{tabular}{ll}
\hline Origin & Around ceauga county \\
\hline Outlet & Erie Lake, Cleveland \\
Outlet elevation & 571 feet $(176 \mathrm{~m})$ \\
Length & $160 \mathrm{Km}$ \\
Bain area & $2095 \mathrm{Km}^{2}$ \\
\hline
\end{tabular}

Table 2. Annual discharge and TDS data

\begin{tabular}{lll}
\hline Year & $\mathrm{Q}\left(\mathrm{ft}^{3} / \mathrm{s}\right)$ & $\mathrm{TDS}(\mathrm{mg} / \mathrm{L})$ \\
\hline 1974 & 4630 & 540 \\
1975 & 1640 & 460 \\
1976 & 680 & 620 \\
1977 & 1230 & 580 \\
1978 & 4930 & 710 \\
1979 & 4670 & 700 \\
1980 & 3910 & 570 \\
1981 & 1500 & 620 \\
1982 & 1080 & 500 \\
1983 & 1260 & 510 \\
1984 & 7640 & 470 \\
1985 & 3070 & 500 \\
\hline
\end{tabular}


Table 3. Partial series with $\mathrm{N}=\mathrm{n}=12$

\begin{tabular}{lll}
\hline $\mathrm{m}$ & $\mathrm{Q}\left(\mathrm{ft}^{3} / \mathrm{s}\right)$ & $\mathrm{TDS}(\mathrm{mg} / \mathrm{L})$ \\
\hline 1 & 7640 & 710 \\
2 & 4930 & 700 \\
3 & 4670 & 700 \\
4 & 4630 & 680 \\
5 & 4590 & 670 \\
6 & 3910 & 620 \\
7 & 3810 & 620 \\
8 & 3070 & 620 \\
9 & 2340 & 580 \\
10 & 1640 & 570 \\
11 & 1500 & 560 \\
12 & 1500 & 550 \\
\hline
\end{tabular}

Table 4. Partial series with $\mathrm{N}=2 \mathrm{n}=24$

\begin{tabular}{lll}
\hline $\mathrm{m}$ & $\mathrm{Q}\left(\mathrm{ft}^{3} / \mathrm{s}\right)$ & $\mathrm{TDS}(\mathrm{mg} / \mathrm{L})$ \\
\hline 1 & 7640 & 710 \\
2 & 4930 & 700 \\
3 & 4670 & 700 \\
4 & 4630 & 680 \\
5 & 4590 & 670 \\
6 & 3910 & 620 \\
7 & 3810 & 620 \\
8 & 3070 & 620 \\
9 & 2340 & 580 \\
10 & 1640 & 570 \\
11 & 1500 & 560 \\
12 & 1500 & 550 \\
13 & 1400 & 550 \\
14 & 1260 & 540 \\
15 & 1230 & 540 \\
16 & 1080 & 530 \\
17 & 1080 & 520 \\
18 & 1060 & 520 \\
19 & 1020 & 510 \\
20 & 920 & 510 \\
21 & 777 & 500 \\
22 & 750 & 500 \\
23 & 741 & 500 \\
24 & 736 & 500 \\
\hline
\end{tabular}

To calculate the probability of the experimental data, the experimental probabilistic Weibull $\left(P=\frac{m}{n+1}\right)$ formula was used.

To study the accuracy of the calculations, the relative error, $E$, percent can be obtained using the following formula:

$$
E=\left(\left(Q_{T}-Q\right) / Q_{T}\right) * 100
$$

where, $Q_{T}$ and $Q$ are the obtained fitted and observed discharge values, respectively.

\begin{tabular}{lll}
\multicolumn{3}{l}{ Table 5. Partial series with $\mathrm{N}=1.64 \mathrm{n}=20$} \\
\hline $\mathrm{m}$ & $\mathrm{Q}\left(\mathrm{ft}^{3} / \mathrm{s}\right)$ & $\mathrm{TDS}(\mathrm{mg} / \mathrm{L})$ \\
\hline 1 & 7640 & 710 \\
2 & 4930 & 700 \\
3 & 4670 & 700 \\
4 & 4630 & 680 \\
5 & 4590 & 670 \\
6 & 3910 & 620 \\
7 & 3810 & 620 \\
8 & 3070 & 620 \\
9 & 2340 & 580 \\
10 & 1640 & 570 \\
11 & 1500 & 560 \\
12 & 1500 & 550 \\
13 & 1400 & 550 \\
14 & 1260 & 540 \\
15 & 1230 & 540 \\
16 & 1080 & 530 \\
17 & 1080 & 520 \\
18 & 1060 & 520 \\
19 & 1020 & 510 \\
20 & 920 & 510 \\
\hline
\end{tabular}

In this study, seven well-known distributions of normal, two-parameter Log-normal, three-parameter Log-normal, Pearson Type III, Log-Pearson Type III, Gumbel or the extreme value Type I and two-parameter Gamma were used.

Given that the two-parameter Log-normal distribution was the dominant distribution in the study area based on the obtained results, the distribution is presented here after.

If the normal logarithm of the random variable $X$, $L n X$, has a normal distribution, the random variable $X$ has a normal logarithmic distribution. In this case it can be written:

$P(X)=\frac{1}{X \sigma_{y} \sqrt{2 \pi}} e^{\frac{\left(\operatorname{Ln}(X)-\mu_{y}\right)^{2}}{2 \sigma_{y}^{2}}}$

where, $\mu_{y}$ and $\sigma_{y}$ are the average and standard deviation of the normal logarithm of $X$, respectively.

If $\operatorname{Ln}(X)$ variable is used as follows:

$T=\frac{\operatorname{Ln}(X)-\mu_{y}}{\sigma_{y}}$

The standard normal variable, $t$ is obtained with the desired probability density function:

$P(t)=\frac{1}{\sqrt{2 \pi}} e^{-\frac{u^{2}}{2}}$

The following equation can be used to calculate the frequency factor of the distribution: 
$K=\frac{e^{\left[\left[\operatorname{Ln}\left(1+Z^{2}\right)\right]^{\frac{1}{2}} t-\left[\operatorname{Ln}\left(1+Z^{2}\right)\right] / 2\right]}-1}{Z}$

$Z=\left(e^{\sigma_{y}^{2}}-1\right)^{1 / 2}$

There are simple methods to determine the best frequency distribution of data and therefore, a more accurate estimation of the data occurrence probability can be obtained.

For fitting the hydrologic data with theoretical distributions, there are various methods from which three methods are used in hydrology. These methods include the use of distribution parameters estimation, distribution coefficient and graphical method. The first method is used in this study and is discussed below (Ostad-AliAskari et al., 2015; 2016; Eskandari et al., 2017; OstadAli-Askari et al., 2015a; 2015b; 2015c; 2015d; 2015e; 2015f; 2015g; 2016h).

The most basic method is to use the distribution parameters. Several methods are used to estimate the parameters, which include Method of Moments (MOM), Maximum Likelihood Method (MLM), Probability Weighted Moment (PWM) Method, Least Squares (LS), Maximum Entropy Method (EMT), Mixed Moments Method (MIX), Generalized Moment Method (GMM) and Incomplete Average Method (ICM). Three methods of the above methods are commonly used including Method of Moments, Maximum Likelihood Method and Probability Weighted Moment method (OstadAli-Askari et al., 2017b; Soltani-Todeshki et al., 2015; Ostad-Ali-Askari et al., 2015; 2016).

The tor Method of Moments is a simple method, but with a few number of data, it will result in a less accurate result. MOM estimates are usually of low quality and generally, it is used less than the MLM estimates. It is not a suitable method particularly for the distributions with a large number of parameters, such as threeparameter distributions and more, whose higher order moments are likely to be skewer in relatively small samples 9 (Eslamian and Koopani, 2002).

The parameters of a probability distribution function are estimated using the MOM method by equating the sample moments with the probability distribution function moments. For a distribution with $K$ parameter, $\alpha_{1}, \alpha_{2}, \ldots$ and $\alpha_{K}$ must be estimated. Then, $K$ sample moments are equated with the moments that are determined based on the unknown parameters. After that, $K$ is simultaneously solved for unknown parameters of $\alpha_{1}, \alpha_{2}, \ldots$ and $\alpha_{K}$.

The Maximum Likelihood Method is highly accurate and seems to be one of the most efficient methods, because it provides the least sampling variance of the estimated parameters. However, the calculations are very complicated and time-consuming, which can be solved using high-speed computers (Table 6).
Table 6. General framework of the Hyfa software output data

\begin{tabular}{llll}
\hline Distribution & Fitted method & $\begin{array}{l}\text { Mean } \\
\text { related.dev }\end{array}$ & $\begin{array}{l}\text { Mean } \\
\text { sq.Rel.dev }\end{array}$ \\
\hline Normal & Moments & 30.6 & 2003.7 \\
& Max. Likelihood & 30.6 & 2003.7 \\
Lognormal & Moments & 27.91 & 941.76 \\
& Max. Likelihood & 27.91 & 941.76 \\
Lognormal & Moments & 23.1 & 810.21 \\
& Max. Likelihood & & \\
\hline
\end{tabular}

\section{Results and Discussion}

By using the Hyfa software, different distributions were fitted to the data and the dominant distribution was selected. For example, the results of an annual discharge data series using the Hyfa software are presented here.

In continue, the best distribution for each of the available data series, including annual and partial $n$, $1.64 \mathrm{n}$ and $2 \mathrm{n}$ data series was separately obtained. The best distribution can be selected in two ways (Sayedipour et al., 2015). The first method is to consider the mean related dev. columns and select the minimum calculated value using the Moments Method as the best distribution. The second method is to consider the means.sq.Rel.dev. column and select the minimum calculated value using the Maximum Likelihood method. The two methods result in the same value in many cases. In Table 7 , the obtained results for the annual discharge series are typically listed and, finally, the final results for selecting the best distribution are presented.

As can be seen from the best distribution Table 8, the two-parameter normal distribution is the dominant distribution of the area. Upon selection of the best distribution, the accuracy of the calculations can be examined by determination of the relative error percent.

The above calculations suggested that the $1.64 \mathrm{n}$ and $2 \mathrm{n}$ series as well as the Maximum Likelihood method are of higher accuracy. The results of the TDS partial series with a length of $2 \mathrm{n}$ as well as the Moment method are typically presented.

Given that the partial series with 20 data presented a higher accuracy than the other series, a comparison between the data with the same return periods in different series with the partial series with 20 data was done. The calculations results indicated that the partial series with 24 data provided the closest estimates to the partial series with 20 data and the lowest accuracy was obtained in the partial series with a length of $n$. Some of the calculations are typically presented below (Table 9-11). 
Table 7. Annual discharge series

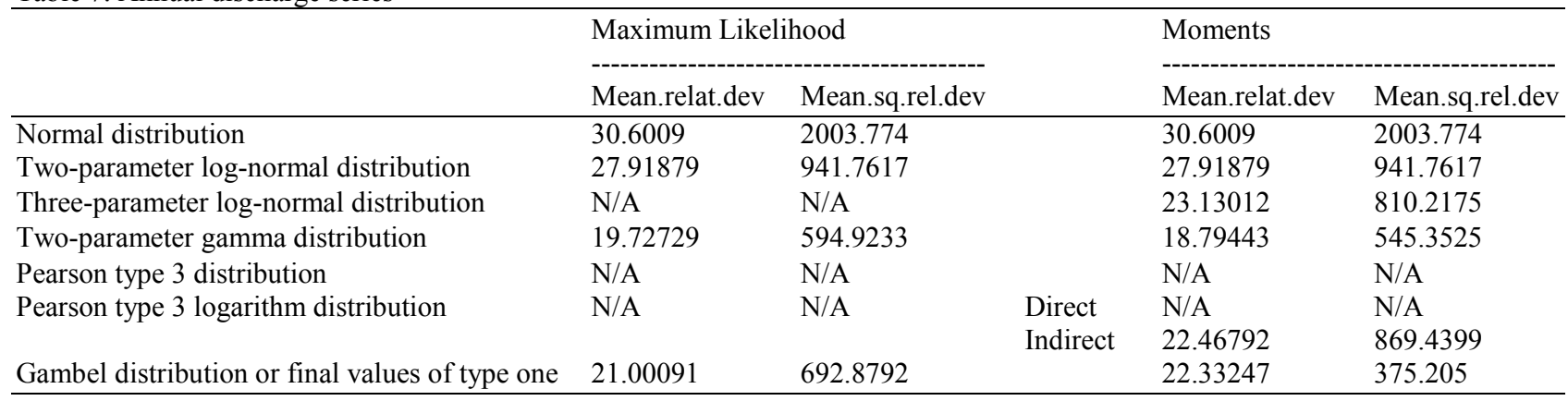

Table 8. TDS annual series

\begin{tabular}{|c|c|c|c|c|}
\hline & \multicolumn{2}{|c|}{ Maximum likelihood } & \multicolumn{2}{|l|}{ Moments } \\
\hline & Mean. relat.dev & Mean. sq.rel.dev & Mean. related.dev & Mean. sq.Rel.dev. \\
\hline Normal distribution & 3.24947 & 15.78051 & 3.24947 & 15.78051 \\
\hline Two-parameter Log-normal distribution & 3.13445 & 19.41524 & 3.13445 & 19.41524 \\
\hline Three-parameter Log-normal distribution & $\mathrm{N} / \mathrm{A}$ & $\mathrm{N} / \mathrm{A}$ & 3.15476 & 22.5043 \\
\hline Two-parameter Gamma Distribution & 3.11434 & 16.68818 & 3.11993 & 17.50947 \\
\hline Pearson type 3 distribution & N/A & $\mathrm{N} / \mathrm{A}$ & $\mathrm{N} / \mathrm{A}$ & $\mathrm{N} / \mathrm{A}$ \\
\hline Pearson type 3 logarithm distribution & N/A & $\mathrm{N} / \mathrm{A}$ & $\mathrm{N} / \mathrm{A}$ & $\mathrm{N} / \mathrm{A}$ \\
\hline Gambel distribution or final values of type one & 3.88466 & 32.33394 & 3.81883 & 33.94466 \\
\hline
\end{tabular}

Table 9. Selection of the best distribution for the qualitative and quantitative data

\begin{tabular}{|c|c|c|c|c|c|}
\hline TDS annual & Two-parameter & Normal distribution & & Two-parameter & Normal distribution \\
\hline series & gamma distribution & & & gamma distribution & \\
\hline TDS partial & Normal distribution & Normal distribution & & Pearson type & Pearson type \\
\hline series with $\mathrm{N}$ & & & & 3 distributions & 3 Distribution \\
\hline $\begin{array}{l}\text { Discharge partial } \\
\text { series with } N=1.64 n\end{array}$ & $\begin{array}{l}\text { Two-parameter Log- } \\
\text { normal distribution }\end{array}$ & $\begin{array}{l}\text { Two-parameter Log- } \\
\text { normal distribution }\end{array}$ & & $\begin{array}{l}\text { two-parameter Log } \\
\text {-normal distribution }\end{array}$ & $\begin{array}{l}\text { Two-parameter Log } \\
\text {-normal distribution }\end{array}$ \\
\hline TDS partial series & Gambel distribution or & Two-parameter Log & & & \\
\hline with $\mathrm{N}=1.64 \mathrm{n}$ & final values of type one & -normal distribution & & $\mathrm{A} / \mathrm{P}$ & $\mathrm{A} / \mathrm{P}$ \\
\hline & & & Ind & $\begin{array}{l}\text { Pearson logarithm } \\
\text { distribution }\end{array}$ & $\begin{array}{l}\text { Pearson logarithm } \\
\text { distribution }\end{array}$ \\
\hline Discharge partial & Two-parameter Log & Two-parameter Log & & Two-parameter Log & Two-parameter Log \\
\hline series with $N=2 n$ & -normal distribution & -normal distribution & & -normal distribution & -normal distribution \\
\hline TDS Partial Series & Two-parameter Log & Two-parameter log & & Two-parameter log & Two-parameter log \\
\hline with N & -normal distribution & ution & & -normal distribution & -normal distribution \\
\hline
\end{tabular}

Table 10. Error calculation (in \%)

\begin{tabular}{lllll}
\hline $\mathrm{T}$ & TDS & $\mathrm{T}$ & $\mathrm{TDS}$ & $\left(\left(\mathrm{Q}_{-} \mathrm{Q}_{\mathrm{T}}\right) / \mathrm{Q}_{\mathrm{T}}\right)^{*} 100$ \\
\hline 1.05 & 493.724 & 1.04 & 500 & 1.25 \\
1.11 & 508.183 & 1.13 & 510 & 0.35 \\
1.25 & 527.861 & 1.25 & 520 & 1.51 \\
2 & 574.145 & 2.00 & 560 & 2.52 \\
5 & 636.420 & 5.00 & 680 & 6.40 \\
\hline
\end{tabular}

Table 11. A typical comparison with $1.64 \mathrm{n}$ partial series

\begin{tabular}{|c|c|c|c|c|}
\hline \multirow[b]{2}{*}{$\mathrm{T}$} & \multicolumn{4}{|c|}{ Maximum likelihood (Two-parameter log-normal) } \\
\hline & $\mathrm{Q}_{\mathrm{T}}$ & $\mathrm{T}$ & $\mathrm{Q}_{20}$ & $\left(\left(\mathrm{Q}-\mathrm{Q}_{\mathrm{T}}\right) / \mathrm{Q}_{\mathrm{T}}\right)^{*} 100$ \\
\hline 1.05 & 562.740 & 1.08 & 763.5950 & 26.30 \\
\hline 1.11 & 846.040 & 1.18 & 962.2820 & 12.07 \\
\hline 1.25 & 1299.77 & 1.30 & 1273.250 & 2.080 \\
\hline 2 & 2569.91 & 2.10 & 2175.536 & 18.12 \\
\hline 5 & 4477.12 & 4.30 & 3717.226 & 20.44 \\
\hline
\end{tabular}




\section{Conclusion and Recommendations}

According to the obtained results, it can be concluded that fitting the hydrologic data with the theoretical distributions can be a suitable method in the qualitative analysis in order to determine the best distribution and use it for estimations. In addition, in quantitative terms, different number of data in the partial and annual series were analyzed and in each case, the obtained error was used as a quantitative indicator for selection of the best number of the data series. According to what was obtained in this study, the partial series with $2 \mathrm{n}$ data provides a better result than a series with $\mathrm{n}$ data, which is suggested to be used in the quantitative and quantitative estimations. It is recommended that the Linear Moment method would be used in future research instead of the Maximum Likelihood method, which is expected to yield more accurate results.

\section{Acknowledgement}

We thank Isfahan University of Technology.

\section{Authors Contribution}

All authors contributed to design the study, write and revise the manuscript. The present study and ethical aspect was approved by Isfahan University of Technology.

\section{Ethics}

The present study was approved by Isfahan University of Technology.

\section{References}

Al-Boodi, J., E. Torabiyan and H. Hashemi, 2002. Qualitative modeling of surface water. Tehran Uni. Publications.

Alizadeh, A., 2005. Fundamentals of the applied hydrology. Emam Reza Uni. Public.

Bahmanpour, H., S. Awhadi, J. Enjili, S.M. Hosseini and V.H. Raeisi et al., 2017. Optimizing absorbent bentonite and evaluation of contaminants removal from petrochemical industries wastewater. Int. J. Constructive Res. Civil Eng., 3; 34-42.

Dehghan, S.H., S.A.A. Kamaneh, S. Eslamian, A. Gandomkar and M. Marani-Barzani et al., 2017. Changes in temperature and precipitation with the analysis of geomorphic basin chaos in Shiraz, Iran. Int. J. Constructive Res. Civil Eng., 3: 50-57.

Efran Manesh, M. and M. Afyouni, 2005. Environmental, water, soil and air pollution. Arkan Public.
Eskandari, S., M. Hoodaji, A. Tahmourespour, A. Abdollahi and T. Mohammadian-Baghi et al., 2017. Bioremediation of polycyclic aromatic hydrocarbons by bacillus licheniformis ATHE9 and bacillus mojavensis ATHE13 as newly strains isolated from oil-contaminated soil. J. Geography, Environ. Earth Sci. Int., 11: 1-11.

Eslamian, S. and S.S. Koopani, 2002. Flood Frequency Analysis. 1st Edn., Arkan Publications.

Eslamian, S., E. Soltani and M. Zaree, 2005. Application of the statistical methods in the environmental sciences. Arkan Public.

Fakhri, M., H. Dokohaki, S. Eslamian, I.F. Farsani and M.R. Farzaneh, 2014. Flow and Sediment Transport Modeling in Rivers. In: Handbook of Engineering Hydrology: Modeling, Climate Changes and Variability, Eslamian, S. (Ed.), CRC Press, Francis and Taylor, ISBN-10: 1466552476, pp: 233-275.

Gupta, R.S., 1989. Hydrology and Hydraulic Systems. 1st Edn., Prentice-Hell, Englewood Cliffs, NJ.

Ostad-Ali-Askari, K. and M. Shayannejad, 2015a. Presenting a mathematical model for estimating the deep percolation due to irrigation. Int. J. Hydraulic Eng., 4: 17-21. DOI: 10.5923/j.ijhe.20150401.03

Ostad-Ali-Askari, K. and M. Shayannejad, 2015b. The study of mixture design for foam bitumen and the polymeric and oil materials function in loose soils consolidation. J. Civil Eng. Res., 5: 39-44. DOI: $10.5923 / j$ j.je. 20150502.04

Ostad-Ali-Askari, K. and M. Shayannejad, 2015c. Developing an optimal design model of furrow irrigation based on the minimum cost and maximum irrigation efficiency. Int. Bull. Water Resources Dev., 3: 18-23.

Ostad-Ali-Askari, K. and M. Shayannejad, 2015d. Optimal design of pressurized irrigation laterals installed on sloping land. Int. J. Agric. Crop Sci., 8: 792-797.

Ostad-Ali-Askari, K. and M. Shayannejad, 2015e. Study of sensitivity of autumnal wheat to under irrigation in shahrekord, Shahrekord City, Iran. Int. J. Agricul. Crop Sci., 8: 602-605.

Ostad-Ali-Askari, K. and M. Shayannejad, 2015f. The reviews of Einstein's equation of logarithmic distribution platform and the process of changes in the speed range of the Karkheh river, Khuzestan province, Iran. Int. J. Dev. Res., 5: 3786-3790.

Ostad-Ali-Askari, K. and M. Shayannejad, 2015g. Usage of rockfill dams in the HEC-RAS software for the purpose of controlling floods. Am. J. Fluid Dynamics, 5: 23-29. DOI: 10.5923/j.ajfd.20150501.03

Ostad-Ali-Askari, K. and M. Shayannejad, 2016h. Flood routing in rivers by muskingum's method with new adjusted coefficients. Int. Water Technol. J., 6: 189-194. 
Ostad-Ali-Askari, K., M. Shayannejad and H. Ghorbanizadee-Kharazi, 2015, Assessment of artificial neural network performance and exponential regression in prediction of effective rainfall. Int. J. Dev. Res., 5: 3791-3794.

Ostad-Ali-Askari, K., M. Shayannejad and H. Ghorbanizadeh-Kharazi, 2017a. Artificial neural network for modeling nitrate pollution of groundwater in marginal area of zayandeh-rood river, Isfahan, Iran. KSCE J. Civil Eng., 21: 134-140. DOI 10.1007/s12205-016-0572-8

Ostad-Ali-Askari, K., M. Shayannejad and S. Eslamian, 2017b. Deficit Irrigation : Optimization Models : Management of Drought and Water Scarcity. In: Handbook of Drought and Water Scarcity: Environmental Impacts and Analysis of Drought and Water, Eslamian, S. and F.A. Eslamian, (Eds.), Taylor and Francis Publisher, USA, pp: 373-389.

Ostad-Ali-Askari, K., M. Shayannejad, S. Eslamian and B. Navab-Pour, 2016. Comparison of solution of Saint-Venant equations by characteristics and finite difference methods for unsteady flow analyzing in open channel. Int. J. Hydrol. Sci. Technol., 6: 9-18.

Raeisi-Vanani, H. ,M. Shayannejad, A.R. Soltani Tudeshki, K. Ostad-Ali-Askari and S. Eslamian et al., 2017a. Development of a new method for determination of infiltration coefficients in furrow irrigation with natural non-uniformity of slope. Sustain. Water Resour. Manag., 3: 163-169.

Raeisi-Vanani, H., A.R. Soltani-Toudeshki, M. Shayannejad, K. Ostad-Ali-Askari and A. Ramesh et al., 2017b. Wastewater and magnetized wastewater effects on soil erosion in furrow irrigation. Int. J. Res. Studies Agric. Sci., 3: 1-14. DOI: $10.20431 / 2454-6224.0308001$

Raeisi-Vanani, H., A.R.T. Soltani, K. Ostad-Ali- Askari and M. Shayannejad, 2015. The effect of heterogeneity due to inappropriate tillage on water advance and recession in furrow irrigation. J. Agric. Sci., 7: 127-136.

Raeisi-Vanani, H., M. Shayannejad, A.R. SoltaniToudeshki, M.A. Arab and S. Eslamian et al., 2017. A simple method for land grading computations and its comparison with Genetic Algorithm (GA) method. Int. J. Res. Studies Agric. Sci., 3: 26-38.
Saadati, S., S. Soltani-Koupai and S.S. Eslamian, 2006. Frequency analysis of meteorological drought using Standard Precipitation Index (SPI). Proceedings of the 1 st Regional Conference on Optimum Utilization of Water Resources in the Karun and Zayanderud Rivers Basins, Zayanderud Basin, pp: 167-167.

Sayedipour, M., K. Ostad-Ali-Askari and M. Shayannejad, 2015. Recovery of run off of the sewage refinery, a factor for balancing the IsfahanBorkhar plain water table in drought crisis situation in Isfahan Province-Iran. Am. J. Environ. Eng., 5: 43-46. DOI: 10.5923/j.ajee.20150502.02

Shayannejad, M., N. Akbari and K. Ostad-Ali-Askari, 2015a. Determination of the nonlinear Muskingum model coefficients using genetic algorithm and numerical solution of the continuity. Int. J. Sci. Basic Applied Res., 21: 1-14.

Shayannejad, M., N. Akbari and K. Ostad-Ali-Askari, 2015b. Study of modifications of the river physical specifications on muskingum coefficients, through employment of genetic algorithm. Int. J. Dev. Res., 5: 3782-3785.

Shayannejad, M., S. Eslamian, A. Gandomkar, M. Marani-Barzani and M. Amoushahi-Khouzani et al., 2017. A proper way to install trapezoidal flumes for measurements in furrow irrigation systems. Int. J. Res. Studies Agric. Sci., 3: 1-5.

Shojaei, N., M. Shafaei-Bejestan, S. Eslamian, M.P. Marani-Barzani and V. Singh et al., 2017. Assessment of drainage slope on the manning coarseness coefficient in mountain area. Int. J. Constructive Res. Civil Eng., 3: 33-40.

Soltani-Todeshki, A.R., H. Raeisi-Vanani, M. Shayannejad and K. Ostad-Ali-Askari, 2015. Effects of magnetized municipal effluent on some chemical properties of soil in furrow irrigation. Int. J. Agric. Crop Sci., 8: 482-489.

Thomann, R.V., 1982. Verification of water quality models. J. Environ. Eng. Division, 108: 923-940. 